\title{
Breve fra J. P. Junggreen.
}

II.

\section{(Ved Hans Lund.)}

\section{J. P. Junggreen til Guslav Johannsen.}

7. Aug. 1880. R. I.

- - - Jeg ønsker forresten meget at tale med dig, men skal nu ud paa en Forretningsrejse i hele næeste Uge. Hvis der" ikke kommer noget i Vejen, vil jeg komme til Flensborg Søndag d. 15. Kl. 10, og skulde du ikke være hjemme til den 'Tid, beder jeg dig sende et Brev herover, til jeg kommer hjem fra min Rejse, hvilket rimeligvis vil skee Fredag Aftell. Jeg skal da ogsaa om muligt tale med Tofte paa Aagaard. Jeg ved ikke, hvor langt det er; maaske vi kunne kjøre derned i en Enspænder (vel at mærke, hvis Tofte, hvad jeg antager, men herom kan du vel vi de Besked, er ell saa paalidelig Mand, at man kan anbetro ham alt).

Der er meget, vi kunde trænge til at tale om. Vi trænge til at gjøre større Anstrengelser end hidtil, hvis sagen skal opretholdes, og der foresvaver mig en Idee om at samle og styrke alle de spredte Kræfter ved Oprettelsen af en Slags Nationalforening.) Men nu kunne vi tale derom, naar vi sees. Jeg har meget at tage vare i Dag. - Det onskede Pibehovede er jeg desværre ikke istand til at skaffe dig. - - - -

1) Der har hersket Uenighed om, hvem Initiativet til Sprogforeningens Dannelse skyldes. "Flensborg Avis" (30. 5.-2. 6., 13. 7. 1894) har villet give Junggreen Aren, "Hejmdal" (31.5. 1894), Gustav Johannsen. Jessen har kaldt C. F. Monrad "Foreningens egentlige Stifter« (Haabets Mænd S. 103). Landsbibliotekar Jakob Petersen synes i sin Afhandling (Sprogforeningens Aarsberetning 1929-30) nærmest at ville mene, at Planen er Gustav Johannsens. Den Artikel i "Flensborg Avis« 15. Dec. 1875, hvor Tanken om Folkebogsamlinger fremsæettes, oIn hvilken Jakob Petersen bemærker, at det er havet over al Tvivl, at Gustav Johannsen er dens Forfatter, er imidlertid skrevet af Jens Jessen efter dennes egen Meddelelse i Fl. Avis 2.6. 94. Efter dette Brev kan der ikke være nogen Tvivl om, at det er Junggreen, der har givet Stødet til de afgørende Forhandlinger. Under Drøftelsen med de to Flensborgere er saa hans oprindeligt mere vidtspandende Planer" bleven a’ndret til den Idé, der udformes i næste Brev. 


\section{J. P. Junggreen til Skrumsager, Fysikus Madvig,}

Moller Jakobsen o. $\mathbf{f l}^{1}$ )

21. Sept. 1879.

Jeg har tit tænkt paa, om det ikke var muligt at gjøre noget i stsrre Maalestok for at modarbejde den ihærdige Virksomhed, Regjeringen udfolder for at fortyske Befolkningen i Nordslesvig. kunne vi det ikke, da er her desværre ingen Tvivl om, at det clanske Folkesprog paa mange Steder er udsat for at udslettes, hvis de nuvarende Tilstande skulle vedvare i en Række Aar. Jeg talte forleden med Gustav Johannsen og C. F. Monrad fra Flenshorg, og vi blev enige om at gjøre et Forsøg paa at bevæge san mange af vore Medborgere som muligt til at yde et aarligt $\mathrm{Bi}$ drag til I thbretlelse af god dansk Læsning rundt om i Nordslesvig, til hvilket Øjemed vi saa ogsaa vilde søge at faa nogen Hjælp fra Danmark. Der bestaar jo allerede nu Biblioteker paa en hel Del Steder, og det er navnlig denne Indretning, vi tænkte os ulvidet til at omfatte, saa vidt muligt, hvert Sogn i den danske Del af Slesvig.

Det er imidlertid et Foretagende, der, for at realiseres, vil krave stor Deltagelse, og vi ønskede derfor at udstede en OpforIring, underskrevet af ansete Mænd fra Landets forskellige Egne, og af forskellige Retninger, hvori vi desværre i den senere Tid er kommen til at gaa.

For at tale om denne Sag, vedtage Opfordringens Form og underskrive den, beder jeg Dem, hvis De kan, at samles med 12 at 14 gode Mænd her i mit Hus Søndag den 26. ds. om Eftermictlagen KI. 1.

Det forekommer mig ogsaa, at det under de nuværende Forlıold vilde være til Gavn, om vi kunde begynde paa et saadant Foretagende, paa hvilket vi jo alle maatte kunne arbejde med Endrægtighed og god Vilje.

1) Dette Brev er ligelydende udsendt til de mulige Deltagere i Samımenkomsten i Aabenraa. - Det er trykt før, nemlig i Sprogforuningens Aarsberetning 1929-30, S. 7 f. Det er Brevet til Fysikus Mativig, som der er afskrevet. Der findes imidlertid en Afvigelse i ciette Brev fra de andre udsendte, idet der i de andre (som her) siges, at baade Gustav Johannsen og C. F. Monrad var med til den afgørende Samtale med Junggreen, mens i Madvig-Brevet Monrad ikke er næunt. 
- - - (Indbydelse til Bestyrelsesmøde i Sprogforeningen, Iler skal læagges en Arbejdsplan) og det kumne vi nu, thi et godt Stykke Arbejde er det lykkedes mig at fuldfore, nemlig at tilvejebringe en Del Penge.

Jeg rejste, som De maaske husker, Dagen efter Modet til Kjobenhavn, hvor jeg benyttede Lejligheden til personligt at tale med Plougt) og Kayser ${ }^{2}$ ) om Sagen. Ploug foranstaltede et lille Mwile hjemme hos sig selv, hvor ogsaa jeg var tilstede, og hvor man blev enig om at sammenkalde et storre Tal af Kjolunhavns Rigmand for paa deme Maade at tilvejebringe en Sum Penge. Dette har fundet Sted i Tirsdags, og der tegnedes straks $2000 \mathrm{Kr}$. aarligt foreløbig i fem Aar, men Ploug haaber at kunne bringe det op til 4, maaske $5000 \mathrm{Kr}$, hvilken Sum jeg forlangte af dem.

\section{J. P. Junggreen til P. A. Madvig.}

14. Novbr. 1880. R. A.

- Ifl. vor Aftale skrev jeg til Boghandler Erslev angaaende $2000 \mathrm{Ex}$. af "Sange og Digte til Danmarks Melodier".

- Jeg fik inidlertid en Betænkelighed, som jeg meddelte Monrad, der jo maa have nogen Erfaring i slige Ting. Den drejele sig om, hvorvilt der ikke kunde lagges os Hindringer i Vejen, naar vi indførte saa stort et Parti af denne Samling. Bøger gaae jo gennem Toldvæsenets Hænder, og det drejer sig jo om en stor Sum, som vi ikke letsindig bør risikere.

Som Svar fik jeg indlagte Brev, som jeg ikke er meget tilfreds med. Det er ikke umuligt, at Monrads Indvendinger tildeels kunne være begrundede, men Samlingen indeholder dog virkelig ogsaa meget godt, og naar vi maa frygte for Indholdet af enkelte, vilde jeg næsten foretrakke, at vi tog disse Blade ud. - - - Selv at lade trykke en Samling synes mig at være et vidtløftigt Arbejde, naar vi først skal enes om et Par Hun-

\footnotetext{
1) Redaktør Carl Ploug. limg

2) Tomrermester H. H. Kayser, Formand for Foreningen »Danne-
} 
drede Sange, dernæst censurere og ændre en Del af dem og derpaa lade dem trykke og indbinde, saa vil det vare længe, inden vi kunne komme til at uddele dem, og Folk vil blive utaalmodige og der hengaa altfor lang Tid, uden at vi gjør noget. - Bekker ${ }^{1}$ ) holder paa den tagne Beslutning og skriver til Lassen og Knudsen'), men har lovet mig at give en objektiv Fremstilling af Sagen. - - Kun een har indtil nu nægtet at have med os at gjøre, Nagel i Høier, ellers har de alle erklæret sig villige, og jeg haaber, de fleste ville gjøre det. $^{3}$ ) $-\ldots$

\section{J. P. Junggreen til P. A. Madvig.}

18. Nov. 1880 . R. A.

- - - Det er tilvisse et stort Savn ikke mundtligt at kunne udvexle sine Inskuelser. Kunde vi det, vilde mangen Uoverensstemmelse let lade sig hreve.

Jeg sender Deres og Skaus Breve til Monrad imorgen, og Knudsens og Lassens skal jeg meddele Dem Indholdet af, saasnart jeg faar dem (Bekker har skrevet til dem). Imorgen Aften sender jeg Opfordring til alle tre Blade. Jeg venter endnu Svar fra nogle af de designerede Kredsformand. Blandt dem, jeg ikke har hørt fra, ere s. Bych i Lunding og Jakobsen i Brøus Mølle. Det er jo dog begge gode Mænd. En Deel har nægtet at tage imod Valget, men de fleste have dog svaret med Ja, og vi kumne møde med et kjønt Antal lige strax. Saa haaber jeg, at vi senere kunne udvikle det videre.

Skulde det nu vare noget, inden vi komme i Gang med Sangbogssagen, saa maa vi skynde os saa meget mere med Uddeling af andre Bøger, og jeg kan forsikre Dem, at hvad der nu 'r skeet, skal ikke gjentage sig. Jeg skal nok betænke mig saa vel, inden jeg enten antager eller forkaster en Bog eller en Forfatter, at Sagen dermed for mit Vedkommende kan være fuldstændig afgjort.

1) Advokat Bekker i Aabenrau, Sprogforeningens Kasserer.

${ }^{2}$ Hans Lassen, Lysabild, og H. O. Knudsen, Trøjborg.

3) Det drejer sig om Opfordringen til at vare Kredsformænd i siprogforeningen. 
Saa vil jeg tuu bede Dem, lad ikke ondt Lune faa Overhaand, men lad os i Kjærlighed og Venskab arbejde sammen med vore Colleger. Det er den eneste Maade at fore Sagen igjennem paa, og denne sag m a ikke gaa i stỵker.

\section{J. P. Junggreen til Meller Jacobsen. 25. Nov. 1880. Privateje.}

- - - Som De vil have seet, var De opfort blandt Kredsíormandene i Dannevirke læenge før jeg havde faaet Deres Brev. Kan De ikke skaffe ell dygtig Mand for Skærba*k Sogn; der har vi ingen, og der kan vist gjøres en behov. Men kan De, saa skaf mig hans Indvilligelse, thi jeg har, som De kan tanke, et umaadeligt skriveri i clemne Ticl. Og gjor Folk opmærksom paa, at naar le ikke kumne give 5 Mk. pr., kunne de give 3 , 2 eller 1 Mk. aarligt, og vi ville endda vare glade ved dem. Forskjellen er jo kun den, at de, der ville give 5 Mk., opføres som Medlemmer og kunne mode ved Generalforsamlingen, hvilket ikke er nogen stor Herlighed. I enhver anden Heuseende ville de, der give mindre, være ligestillede med Medlenmer, thi Foreningen vil jo ikke blot arbejde for at holde Danskheden oppe iblandt sine Medlemmer, men saa vidt muligt hos hele Folket. Den vil være ydende, saavidt dens Kræfter rækker, og jeg haaber, de skulle række ikke saa kort.

Nogle Medlemmer i hver Kreds haaber jeg vi faar, og saa. skulle smaa Bidrag ogsaa være meget velkomme.

Jeg længes efter, at vi ret kunde komme til at arbejde, men der er meget at gjøre, inden en saadan Organisation er kaldt tillive over hele Landet.

\section{J. P. Junggreen til P. A. Madvig.}

28. Nov. 1880 . R. A.

- - - Monrad har nu ogsaa sendt et Forslag til Indkjob af Boger. En Del af de Boger, han navner, er meget gode, men andre finder jeg ganske uhensigtsmæssige og savner desuden meget af, hvad jeg synes burde være der. Jeg taler i Dag med Bekker derom, og saa er det faldet mig ind, om det ikke kunde vare godt, at De og jeg ogsaa gjennemsaa Listen, for- 
inden vi den 9. forelægger dell til endelig Vedtagelse. Og hvad mener De, on vi tog Mork Hansen ${ }^{1}$ ) paa Raad. Han er jo en stor Bibliofil og veed navnlig vistnok meget godt Beskeed om populær historiske Skrifter, der jo dog heller ikke burde savnes, om det end er vist, at vi overvejende bor holde os til god æstethisk Litteratur med et patriotisk Anstrøg. -

\section{J. P. Junggreen til P. A. Madvig. 2 Dec. 1880. R. A.}

Hermed sender jeg Dem Monrads Forslag til Bogindkjøb. Jeg har understreget, hvad jeg finder passende. Men vi maa have mere; thi min Mening er, at vi skulde etablere smaa Bibliotheker, hvor de savnes, af $\mathrm{i}$ det mindste 50 gode Bøger, og der kan jo være mange tildeels bedre Bøger end nogle af disse. Desuden vilde jeg have noget populært historisk, geografisk og naturhistorisk med. Jeg vilde onske, De havde bestemt Dem til nu strax at faa Mork-Hansen og Nansen²) ned til Dem, og at jeg saa med det samme var kommet derover, hvorved vi vistnok kunde have klaret Sagen paa en Eftermiddag, thi jeg længes efter, at vi ret kunme begynde vor Virksomhed. Der vil jo saa alligevel gaa nogen Tid hen.

\section{J. P. Junggreen til P. A. Madvig.}

10. Dec. 1880. R. A.

Først beder jeg Dem og Deres Hustru modtage min Tak for den Venlighed, De viste mig forleden, og dernæst meddeler jeg Dem, at jeg har ansat et Bestyrelsesmøde til Søndagen den 19. Kl. 1, hvor saavel Sangbogssagen som Bogudvalget $\mathrm{s} k \mathrm{u}$ l l e finde deres endelige Afgjørelse. De seer, jeg taler kategorisk, thi jeg nødes nu til at gaa saaledes frem, naar ikke det hele skal opløse sig i lutter Vrøvl, skjønt det ellers er min Natur imod. Jeg beder Dem derfor, hvis det paa nogen Maade er muligt, at komme.

1) M. Mork Hansen, tidligere Prast i Felsted, nu i Vonsild-Ilalby.

2) Pastor Nansen i Taps. 
Vi bleve jo saa dømte i Gaar (som ventet). ${ }^{1}$ )

Knudsen fra Trøjborg var her i Anledning af en landøkonomisk Forsamling, og han var her hos mig en Timestid i Aftes. Han gjorde det Forslag, at han, der synes at være en ivrig Sanger og at eie Alverdens Sangbøger, vilde inden næste Søndag gjennemsee Danmarks Melodier, udskyde, hvad han fandt mindre passende og istedetfor tilføje andre gode Sange af nyere Samlinger, og vi da lod det saaledes fremkomne Udvalg trykke. Det vilde $i$ det mindste have det Fortrin fremfor Monrads Ide$\in \mathrm{r}$, at vi saa med det samme uden videre Forhandlinger havde (n Text, medens jeg er bange for, at naar Monrad skal til at revidere Lohmanns Samling²) og saa lade denne trykke, vil dette hive et meget vidtloftigt Arbejde.

E f t e r sk r if t: Sagen er nemlig den, at Bekker er lige saa uvillig som før til at gaa ind paa Monrads Ideer, og vi maa dog have en Ende paa Sagen. Jeg tilføjer disse Ord, da De vel ellers næppe kan forstaa, hvorfor jeg er bleven saa ivrig.

\section{J. P. Junggreen til Skrumsager.}

19. Dec. 1880. Privateje.

Jeg hører, at der nordoppe er megen Utilfredshed med Bidragets Størrelse. Her i Byen har der intet været af sligt. Folk har givet rigtig godt og villigt, fra 10 Mk. til 1 Mk., men vi skulle jo gerne have alle med, og jeg vil lerfor paa den forste Generalforsamling foreslaa, at vi erklære alle dem for Medlemmer, der har tegnet sig for et Bjdrag af I Mk. aarligt eller mere -

Ii have nu gjort et saa stort Indkjøb af gode danske Boyer, at vi først i Nytaaret haabe at kunne oprette $60 \mathrm{ny}$ smar Folkebibliotheker rundt om i Landet foruden at forsyne de allerede bestaaende med et mindre Antal gode Bøger. Naar

1) Sprogforeningens Bestyreise blev mulkteret for at have indkaldt til Made, uden at Tilladelse var indhentet hos Politimesteren. lla en saadan Tilladelse kun krævedes af politiske Foreninger, og det hetød en Del, at Sprogforeningen ikke hetragtedes som en saadan. indankerle Bestyrelsen Sagen for Aintsretten, der den 9. Dec. idomite Junggreen og Bekker en Bøde hver paa $24 \mathrm{Mk}$. og de øvrige Bestyrelsesmedlemmer $15 \mathrm{Mk}$. hver.

2) Pastor Iohmanns wl)ansk sanghogu. 
vi nu have faaet dem indbundne, lober vore Omkostninger dermed op til over $8000 \mathrm{Kr}$., og endskjønt dette er et stort Beløb, ville vi dog kumne klare det, naar Bonderne blot ville stotte os nogenlunde, thi Kjøbstadsbefolkningen har vist sig villig og redebon - - - -

\section{J. P. Junggreen til P. A. Madvig.}

21. Dec. 1880. R. A.

Ogsaa jeg havde meget ønsket, at De havde været her. $H$. Lassen var her heller ikke, og Monrad rejste Kl. 4. Han kom nemlig fra Kjøbenhavn, hvor han havde besørget det Bogindkjøb, vi havde talt om. Det har han gjort godt. Da Monrad var her, gik Bekker og Knudsen og Skau ind paa, at der skulde skydes ud og sattes til af Danmarks Melodier, at Knudsen skulde besørge dette, og det saaledes fremkomne trykkes. Et Forsøg viste imidlertid, at dette havde sine store Vanskeligheder, og til syvende og sidst gik Knudsen og skau fuldstandig ind paa Deres og Bekkers Anskuelse.

Som Sagen ligger, vil jeg imidlertid have en Idtalelse fra alle Medlemmer af Bestyrelsen, og jeg vil derfor opfordre Bekker og Momrad til i Korthed at formulere deres Forslag, og dette vil jeg saa sende til Dem og bede Dem sende det til skau, der sender til Knudsen o. s. v., idet jeg beder ethvert Bestyrelsesmedlem at bemærke, for hvilket af de to Forslag han stenımer. Paa denne Maade faar Sagen en Ende. Det vil dog vare lidt enduu, inden jeg gjør det; jeg vil først se, hvorledes Finantserne stille sig. Bogindkjøbet løber op til over $6000 \mathrm{Kr}$. (foruden $33^{1 / 3} \%$ Rabat) og med Indbinding og ovrige Udgifter vil let blive $8000 \mathrm{Kr}$. De 6000 dækker Kayser af det for i Aar. og næste Aar lovede Beløb, men saa skulle vi jo endnu bruge over $2000 \mathrm{Kr}$., og jeg naa desværre sige Dem, at hvad jeg hører rundt om fra Landet, lvder ikke meget opmuntrende. Overalt kun Klager over, at Bidraget er for højt, og at man kun kan faa ellkelte Medlemmer. Værst er det $\mathrm{i}$ den nordvestlige Egn af Haderslev Aimt, der hvor man skulde have troet, at alt vilde have gaaet saa saare let. Derfra faar jeg intet andet end 
Jammerhyl over de $\mathbf{J}$ Mk. Derimod har Befolkningen her $i$ Bỵen vist sig meget villig.

- - Vil De ikke bede Kredsformandene at gjore leres Bedste og gjøre det snart. Vi skulle med det forste bruge en betydelig Sum, og alt hvad jeg til Dato har faaet indbetalt fra Landet, er $40 \mathrm{Mk}$. Alt dette er ikke meget ly-steligt. men sagen $\mathrm{s}$ a $l$ gjennemføres. Blamagen var altfor stor, hris den ikke blev det.

\section{J. P. Junggreen til P. A. Madvig. 26. Dec. 1880 . R. A.}

Jeg skal være hos Dem paa (Onsdag Middag og medbringe de Beretninger, jeg har faaet fra Haderslev Amt Ost for Jernbamen. Saa kumue vi gjole et Udkast til Bibliothekernes Fordeling i denne Del af Landet. I hvert Sogn kumne vi jo ikke give dem, og det gjalder altsaa on at gjøre det rigtige Udvalg.

Siden jeg skrev til Dem sidst, har jeg faaet glædelige Efterretuinger fra adskillige steder. Wildfang i sverdrup har sendt 151 Mlk., fra Sottrup har jeg faaet 82 , og i IIllerup Sogn er der samlet 44 Medlemmer, ogsaa i Spandet Sogn en Del. Kun helt nord oppe, i Kjøbenhoved, Radding. Skodborg etc. er der ingen, der kalı give 5 Mk. om Aaret for at stotte Sagen, netop der, hvorfra man skulde have ventet ganske almindelig Tilslutning.

Maaske er Bidraget jo sat vel højt, men nu maa Sagen yaa sin Gang, og om det senere skal nedsattes, kan jo blive rjenstand for Forhandling paa den forste Generalforsamling.

\section{J. P. Junggreen til Skrumsager.}

18. Marts 1881. Privateje.

Foreningen trives meget godt. Vi har nu udsendt en forste Sending Bøger, rigelig $40 \mathrm{Bind}$, til omtrent 80 steder, altsaa i det hele over 3000 Bind, og der er endnu et lignende noget storre Parti i Arbejde, som vil blive omdelt, saa snart det er færdigt. Men det er jo et stort Arbejde, og den vanskelige Forbindelse med Kjøbenhavn har ogsaa forsinket os. Der ligger enthu Bogpakker til os i Korsør. Vi var 
samlede lige efter den 15 . Februar for at bestemme, livor Bibliothekerne skulde anbringes, og der var jo to Hensyn at tage. For det forste Trangen. Hvor der allerede var Bibliotheker. hastedle det jo ikke saa stærkt; og dernæst den Interesse, de forskellige Distrikter havde vist for lioreningens Formaal. Vi var nødt til at tage noget Hensyn dertil, thi Bidragene var indkommet meget forskelligt. Ullerup Sogn har saaledes givet 240 Mk., Xsby 220, Kjøbstæderue ogsaa flere Hundrede og desuden mange sogne fra 50 til $100 \mathrm{Mk}$. Det var af begge disse Grunde, at vi den Gang forbigik Dem. Jeg vidste jo, at De havde et Bibliothek, og saa havde Kjøbenhoved vist saa liden Interesse for Sagen, at vi nasten troede, de ikke vilde have noget med os at gjøre deroppe. Det glæder mig meget, at der nu begynder at vise sig nogen Interesse for den. Nu i April Maaned vil jeg sammenkalde en Generalforsanıling og: foreslaa en Nedisættelse af Bidraget; saa haaber jeg, Deres Egn ogsaa konmmer med. Jeg skal endnu i Dag skrive til Monrad, at han skal sende Dem en Fortegnelse over de Boger, vi har, saa kan De delaf faa, hvad De ikke har i Deres Bil-liothek. Vor hele Indtagt har til nu varet rigelig 5000 Mk., medens de Buger, vi har anskaffet, lober op til omtrent 10,000, og desuden har vi endnu et andet Foretagende uncler Forberedelse, der vil koste os 15-1600. Men vi el ikke bange for Pengesporgsmaalet. Der vedbliver stadigt at komme Bidrag; endog fra udvandrede Nordslesvigere i Nordamerika har jeg faaet et Bidrag og Løfte om flere.

Alt gaar godt, og med Guds Hjalp skal vor Forening nok gjøre Gavn.

\section{Junggreen til P. A. Madvig.}

1. Juli 1881. R. A.

Jeg har nu skrevet til Krüger, forestillet ham det onskelige $i$, at vi dog $i$ det mindste var repræsenterede $i$ een af de storre Forsamlinger, og da han, efter hvad jeg vidste, ikke var istand til at indtage sin Plads i Rigsdagen, foreslaaet, at vi nu ved naste Valg opstillede Gustav Johannsen. 
Jeg har tillige hentydet til de Vanskeligheder, der let kunde opstaa ved de Modsætninger, der jo ogsaa er tilstede $i$ vort Folk, hvis denne Sag blev henstaaende uafgjort, til maaske haade han og jeg og flere af de faa, hvis Indflydelse strækker sig over hele Folket, var døde, og jeg tilbød ham, at jeg, hvis han onskede det, vilde komme ud til, ham for at tale med ham om Sagen.

Var det nu ikke maaske rigtigst, om De ventede med at rejse ud til ham, til jeg paa en eller anden Maade har hørt fra ham, Ierom vil De, der kjender ham bedre end jeg, bedst selv kunne domme. Jeg har en Folelse af, at han maaske kunde blive stædig, naar vi trænger fcr haardt ind paa ham paa een Gang.

Jeg var jo saa i Ryslinge ${ }^{1}$ ) og talte til Folket saa godt, son jeg kunde, om at opgive den indre Strid og slutte sig sammen om den ene store Sag, at sætte Forsvarsvæsnet i behørig Stand. Jeg føler desværre ved slige Lejligheder ret, hvor daarlig begavet jeg er som Taler, men troer dog, jeg har gjort nogen Nytte. Det lader til, at alle Mennesker er kede af Tilstandene clerovre, og kunde mit Raad trænge frem til Kongen, da vilde jeg rade ham til at forsuge med et andet Ministeriun. thi efter alt, hvad jeg har kumnet mærke, er Estrups Personlighed een af de vasentligste Hindringer for en Udjævining.

Mænd som Birkedal, A. D. Jørgensen og mange flere saa Tingene saaledes, og om deres gode Vilje er der ikke Tvivl. A. D. Jorgensen holdt et prægtigt Foredrag om Slesvigs Historie, men var nærved at fortvivle over Forholdene, d. v. s. der parlamentariske Forhold. Dog derved kunne vi jo intet gjøre, vi have nok at bestille med vore egne Sager, hvad dog tilvisse cgsaa vilde vare lettere for os, naar Tilstandene i Kongeriget vare bedre.

1) Junggreen talte vel 2 Morler paa Ryslingeegnen, den 26 . Juni i Torpegaard Skov ved Sdr. Næraa, den 27. Juni i Hojby. Talerne er foruden Junggreen bl. a. Red. Willemoes, Odense, Arkivar A. D. Jorgensen, Prasterne Clausen, Nr. Lyndelse, V. Birkedal, Ryslinge, og Svejstrup, Vejen. 
Jeg har jo - - skrevet til Hans Krüger og fik igaar Brev fra hals Søster, hvori hun meddelte mig, at han var saa syg, at hall ikke kunde svare. Hun syntes derfor næstell intet Haab at nære om, at han kunde komme sig. Jeg antager, at J)e veed nogen Besked derom og beder Dem med det for'ste sige mig Deres Mening om, hvad vi bor gjøre. Ret lange kumne vi ikke opsætte at tage en Bestemmelse, thi ingen veed jo, naar Rigsdagsvalget kommer. Der er vel bleven talt rom september, men forleden saa jeg et Telegram fra Berlin, -tler sagde, at Rigsdagsvalget rimeligves vilde komme for, end man havde troet. Nogen Tid maa vi dog have til at forberede Valget.

Jeg antager, at De kommer til Beftoft og beder Dem om inuligt foranledige $K$. til at yttre sig om, om han har noget imod, at vi indkalde en Forsamling for at blive enige om en Candiclat. Kunde De faa ham til at underskrive en Smule Er. klæring om, at han ikke vil vælges og beder om at valge en anden, var det jo det bedste.

Skeer det (een af Tingene) saa beder jeg Dem skaffe mig nogle faa Mænds Indvilligelse til at sammenkalde Valgmændene for at raadslaa om en Candidat. Det forekommer mig, at -dette er den Corporation, der bedst egner sig til dette Brug, den $\mathrm{rl}$ jo dog direkte valgt af Folket.

(J. mener det bedst, at han aleie sammenkalder Modet) fordi man ved at gjøre et Udvalg aldrig undgaar at støde een wler anden for Hovedet. Det har jeg prøvet tit nok. Hvis De, naar De billiger min Plan, og naar Tiden er kommen, vilde skrive til Skrumsager, Eliassen (?) og Hörlyck i Rurup eller Thounsen i Roost samt et Par Mænd i Haderslev Østeramt deron, vilde jeg vare I)em forbunden. Jeg skal da skrive til mogle Mrand i det uvrige Land. Jeg onsker ikke at gjor det uden en Slags Bemyndigelse, da man ellers kunde betragte det rom en Ammasselse fra min side. 
Jeg har i Dag skrevet til Hans Lassen, meddelt ham min Plan og spurgt, om han havile noget imod, at jeg sammenkaldte Valgmændene. Naar jeg faar Svar fra ham, vil jeg tage en Vogn og kjøre ud til Beftoft for selv at see, hvad der er at gjøre, ta Sagen jo paa een eller anden Maade maa bringes til Ende. Jeg har i Dag talt med Fausbøl., ${ }^{1}$ Han sagde intet om, at nogen havde talt med Krüger, men fortalte mig derimod, at de var imod Gustav Johannsen og hellere vilde stemme paa Hans Lassell, hvad jeg slet ikke havde troet. Skulde dette blive en almindelig Anskuelse blandt Valgmandene, skal jeg ikke sætte mig derimod, skjant jeg, hvis Valget stod til mig, lang t vilde foretrække Gustav Johannsen. Jeg selv kan desværre ikke. De veel kun lidt, hvor usselt jeg har det, og jeg har jo ogsaa, som De selv veed, en stor politisk Virksomhed herhjemme. Og stillingen $i$ Berlin er meget vanskelig, langt vanskeligere, end da den valgte havde $\$ 5$ at stutte sig til. Da hehøvede han kun at foreholde dem den og vi forlangte kun, at de skulde udfore, hvad de havde forpligtet sig til. Nu kan vor Rigsdagsmand kun appellere til den almindelige Retsfølelse , foreholde dem det lumpne $\mathrm{i}$ saaledes at unddrage sig Opfyldelsen af indgaaede Forpligtelser og den store Uret, de have begaaet imod Danmark ved at fratage det et Stykke Land, der var ubetydeligt for den $\mathrm{S}$ tore, men stort for den lille.

Derfor trænge vi nu til at have en rask og rorig Mand dernecle, ter kan benytte de Lejligheder, der frembyde sig. Thi de kumme blive faa nok, og lerfor kan jeg ikke overtage stillingen uden $i$ alleryderste Nodstilfalde, naar det skulde vise sig u m u ig t paa anden Made at tilvejebringe Enighed.

\section{J. P. Junggreen til Gustav Johannsen.}

22. Juli 1881. R. A.

Tak for dit Brev. Jeg kjenter dit varme danske Hjerte og anseer dig ogsaa ellers for at være den af os, der vilde være

1) Maller Fauslial, Branderup. 
bedst skikket til at afløse Krüger. Dette har jeg ogsaa sagt overalt, og jeg troer ogsaa nok, du i mange Kredse har Stemningen for dig. Hvis du eller Monrad har Venner i Vesteregnen, saa see der at paavirke Stemningen saa meget som muligt. Jeg er nu nødt til at holde mig noget tilbage, thi jeg maatte love Krüger ${ }^{1}$ ) ikke at foreslaa nogen Kandidat. Saa meget kan jeg dog sige dig, at baade Madvig og Skau ere vundne for dig. En Vanskelighed ligger i Forholdet til Hans Lassen. Skulde han ønske at vælges, vil det jo være vel baade umuligt og usømmeligt at overtale Valgmandene fra Als og Sundeved til at stemme imod ham, thi han har jo, hvor han har været, rogtet sin Gerning godt, og jeg har intet imoul, at han opstilles, kun at jeg mener, at du er i Besiddelse af Egenskaber, der vilde gjøre det lettere for dig at optræde med Virkning i Rigsdagen, end det vil vare for ham. Ved du noget om, hvad han tæenker i denme Henseende, og troer du ellers ikke, at en ligefrem Henvendelse enten af dig eller Monrad til ham kunde være til Gavn. Hvis han ikke bryder sig om at virlges, vilde du vist kunne vinde Valgmændene fra Als og Sundever for dig, og saa troer jeg let, det vilde gaa. Tænk derpaa og lad inig vide, hvad du vil og troer at kumne gjore. Vorherre give. at det maatte gaa, som du og jeg onsker.

For din Advarsel takker jeg. Vi faa jo at see, hvad de ville gjøre. Dog kan jeg oprigtigt talt ikke indsee, hvorleiles de skulde komme os tillivs. At uddele ikke forbudte Boger, der kunde kjøbes i enhver Boglade, kan dog ikke vare nogen Forbrydelse, og cleri har jo til Dels vor hele V'irksomhed bestaaet.

Hvad jeg aldeles privat har gjort, mine Avisartikler, nit Brev til Moltke etc. kan dog næppe lægges Foreningen til Last. Vi ville altsaa ganske roligt afvente, hvad der kommer, men naturligvis vare meget forsigtige.

1) Junggreen har den 15. Juli heswgrt Krüger, der hilliger, at der indkaldes en Forsamling for at enes om hans Eftermand. Kan der ikke naas Enighed, kan man stenme par ham igen. Junggreen indbyder da Valgmandene til et Made i Aabenrata 2 . August. 
Lad mig nu vide, om du mener selv at kumne sætte dig i Forbindelse med H. Lassen, du eller Monrad. ${ }^{1}$ ) Jeg ønsker det meget, og jeg maa ellers see at finde paa andet Raad. Gud give, at alt maa gaa godt.

\section{J. P. Junggreen til Moller Jacobsen.}

22. Juli 1881. Privateje.

Jeg stolede sikkert paa, at De var eller havde været Valgmand, men saa alligevel gjerne, at De kom herhen. Tage Del i Afstemningen kan loe ikke, (la jeg jo udtrykkeligt kun har inclbudt Valgmandene, men være tilstede nede paa Hotel Danmark og tale med Folkene, mener jeg godt, De kan. Jeg vil saa, forinden der finder Afstemning Sted, udtrykkeligt udtale, at kun Valgmiend ere berettigede til at stemme, og bede dem, ler muligvis maatte have veret tilstede som Tilhørere, fjerne sig, medens Afstemmingen fincler sted. Det var meget kedeligt. De veed gorlt, hvor stor Pris jeg sætter paa Dem, og jeg havde just paaregnet Dem som en af dem, der skulde hjælpe med til at styre alt til det gode.

Hvad den bestemte Dag angaar, da kan jeg jo nu umuligt foramlre denne. Det vilde let kume bringe hele Sagen i Forvirring, ogsaa synes mig, at de Folk i Sandhed kun maa have meget liden Interesse for Nordslesvigs folkelige Livssag, der ikke kunde komme her, fordi der skal være Møde paa Askov.") Nlle de Ting, De nawner i Deres Brev, kumme jo kun have teoretisk Interesse for dem. Her er jo i denne Henseende Frihed nok. Om Folk ville kirkelig vies, eller om de ville lade deres Burn døbes og confirmeres, staaer jo her helt til dem selv, og ligger det dem endeligt saa meget paa Hjertet at komme til

1) Gustav Johannsen henvender sig skriftligt til Hans Lassen, der straks den 23. 7. svarer, at han gerne vil have en Samtale med ham i Sønderborg den $26 . \%$. Der er nok bleven yntet om, at man vilde opstille ham, men han er nxesten nodsaget til at holde paa, at le skal stemme paa en anden, da landlag hvol "vi i Frenıticlen maa tage mere aktiv Del i Forhandlingen provinslandlag. Kredsdag og en Del andle kommunale Bestillinger giver ham nok at hestille.

2) Der holdes paa Astor Hojskole et Morle orn the kirkelige FriLrisktar 2.-4. August. 
Askov, saa kumne de jo komme der den 3die om Morgenen. Om Aftenen kunne de komme herfra og til Vamdrup, og saa vistnok straks om Morgenen til Askov.

Interessen for vor Sag maa ikke være stor for dem, der ikke ville komme herhen til dette Valg, det vigtigste, vi have foretaget i mange Aar. Gud give, at alt maatte faa et godt lidfald.

\section{J. P. Junggreen til H. R. Hiort-Lorenzen. 24. Juli 1881. K. B.}

Endnu igaar vilde jeg have svaret Dem, at det næppe lønnede Umagen at sende en Referent hertil, da jeg haabede, at Debatten kunde have været indskrænket til det mindst mulige. Jdag er det imidlertid anderledes, thi jeg seer nu af Dannevirke, at der i Haderslev Vesteramt rejses en Agitation for at vedblive at vælge Krüger, uagtet han nu er saaledes, at det er positivt umuligt at repræsentere Folket, hvad han ogsaa selv erkjender, og uagtet han udtrykkeligt til mig har erklæret, at han billiger, at Valgmændene paa den af mig foreslaaede Maade udpege en Mand til hans Efterfølger. Det kan saaledes maaske blive livligt nok. - - -

\section{J. P. Junggreen til C. F. Monrad.}

24. Juli 1881. R. A. (Gustav Johannsens Arkiv).

Dette er det andet Brev, jeg skriver til Den i Dag, men jeg er i Forlegenhed og ved ingen anden at henvende mig til end Dem. De har vel seet, hvad der stod i Dannevirke i Aftes: De to Udtalelser om atter at vælge Krüger. Jeg troede, at den hellige Grav var vel forvaret, da jeg fik hans fuldstæendige Indvilligelse til at gaa frem, som jeg foreslog, men det synes jo ikke at være Vesterboerne nok, og efter meget, som jeg har hørt idag, venter jeg ikke andet end Uenighed og Spektakler af vort Møde, naar man ikke kan bevæge Krüger til selv offentlig at erklære, at han ikke ønsker, at vælges igjen, eller at han nu vil anbefale at vælge en anden. Gjør han det.ikke, eller har han ikke udtalt sig saaledes til dem, der rimeligvis have været 
hos ham, saa gjør han en stor Uret mod mig, thi havde han jkke billiget, at jeg udstedte min Opfordring, var den ikke fremkommet.

Nu er min Bøn til Dem, at De om muligt med clet forste Tog imorgen, hvormed De kan komme af ved Jersdal, eller medl Iltoget, der sætter Dem af ved Vojens, vil see at komme til Beftoft, for, hvis det er muligt, at see at faa ham til at underskrive en saadan Erklæring, som da samtidigt maa offentliggjøres i Bladene, eller hvis dette tager for lang Tid, da $\mathrm{f} ø \mathrm{r} s \mathrm{~T}$ i D n v., hvori det er nødvendigt.

Jeg selv kan ikke paa nogen Maade rejse i Morgell, og Sagen kall ikke opsattes, og derfor henvender jeg mig til Den. Jeg ved ingen anden. I Haderslev tror jeg ikke, der er nogen, der kan udrette noget hos Krüger. Hils ham fra mig og sig ham, at jeg beder ham indstændigt om at gjore det, da vi ellers risikerer Lenighed, hvilket jo vilde være det sørgeligste af alt. Jeg var efter hans Idtalelser til mig fuldstændig berettiget til at antage, at der ikke vilde fremkomme den Salgs Indvendinger ellers var jo som sagt Indbydelsen ikke fremkommen.

Meddel mig s narest nu u ig t Udfaldet af Deres Bestrobelser og modtag i Forvejen min Tak for den Tjeneste, De gjørSagen. ${ }^{1}$ )

\section{J. P. Junggreen til Gustav Johannsen.}

28. Juli 1881. R. A.

Vil du paa mine Vegne indbyde Monrad til Mødet. Jeg tænker Erklæringen²) kommer i Dnv. i Aften, men den vil forresten ikke nytte os noget. Jeg ved nu, hvorledes Sagen hænger sammen. Det er Krüger, der spiller dobbelt Spil. Medenshan vel tilstaar, at han har billiget min Indbydelse, udtaler han sig dog saaledes, at Folk faar den Mening ud deraf, at han alligevel vil vælges igjen. Det har en af hans Tilhrengere,

\footnotetext{
1) Det blev ikke Monrad, men Gustav Johannsen, dej den 26 . Juli rejste til Bevtoft og talte med Krüger.

$\left.{ }^{2}\right)$ Den Erklæring fra Krüger, som Gustav Johannsen har lragt med fr't sit Besøg i Bevtoft (jfr. Brev 29. Juli).
} 
Hørlyck i Rurup, været naiv nok til at skrive til mig, samtidig med at han opfordrer mig til at tilbagekalde Modet, da de derude ikke kunde være med til at vrage deres gamle Reprasentant. $\left.{ }^{2}\right)$ Jeg har skrevet ham et Brev tilbage, der havde baade Næb og Klør, thi er vel nogensinde en Mand bleven behandlet paa en saa lumpen Maade som jeg ved denne Lejlighed af Krüger.

Just for at høre, om han billigede, hvad jeg paatænkte, rejste jeg ud til ham, og havde han blot antydet, at det ikke havde hans Bifald, var Indbydelsen jo aldrig fremkommet. Istedetfor dette samtykker han fuldstændig $\mathrm{i}$ alt, hvad der nu er sket, og optræder saa bagefter saaledes. Det er næsten til at blive gal over.

()g dog maa vi paa Mødet see at bevare Enigheden - om muligt. Jeg skal gjøre dertil, hvad jeg kan. Men høre, hvad vi have at sige, skulle de dog. Jeg har ikke villet skrive derom for ikke at give Anledning til mere Strid.

Lev vel, kjære Ven. Jeg skriver dette i stor Hast.

\section{J. P. Junggreen til Moller Jacobsen. 29. Juli 1881. Privateje.}

Jeg takker Dem for Deres Brev, og endnu mere for Deres smukke Artikel, som jeg i Aftes læste i Dnv., og som jeg haaber vil værr istand til at slaae alt det Vrøvl til Jorden, som er kommet frem fra den anden Side. Naar jeg ikke selv har skrevet noget, da var det, fordi jeg var bange for at gyde Olie i Ilden, thi jeg troer ikke, at jeg denne Gang vilde have kunnet skrive med den Ro, som var nødvendig. Jeg er i denne Sag bleven behandlet paa en saa lumpen Maade som aldrig for $i$ mit Liv. - Efter hele den Maade, hvorpaa jeg var gaaet frem, var

1) I Brevet fra A. D. Hørlyck og H. Thomsen hedder det, at de af Krügers egen Mund har hørt, "at han vel billiger Deres Indbydelse, men at han - naar det kommer til Stykket - dog helst vil ve d blive at være Rigsdagsmand, og mener vi, at vi ere ham skyldige især her $\mathrm{i}$ 1ste Valgdistrikt (Haderslev og Als) - ikke at vrage ham, saalænge han lever. Det ville vi heller ikke paa nogen Maade gjøre - det ere vi alle enige om - og heller ikke ville vi tanke paa at udsee eller være med til at udsee hans evt. Efterfølger, saa længe han lever«. Derfor beder de om, at J. vil aflyse Mødet 2. August. 
jeg ikke istand til at begribe, hvad Aarsagen var til alle disse forfærdelige Klager over al den Krænkelse, der skulde være tilføjet Krüger ved Sammenkaldelsen af denne Forsamling, thi forinden jeg udsendte Indbydelsen, havde jeg faaet hans Samtykke dertil, og havde han, da jeg var hos ham, blot antydet, at han onskede at vælges, var Indbydelsen aldrig fremkommen, da jeg saa godt vidste, at den kun vilde give Anledning til splid og strid. Istedetfor at gjore dette sagde han til mig, at han ikke længere var istand til at repræsentere Kredsen, og at lian fuldstandig billigede, at jeg gik frem paa den Maade, som nu skeet er. I Forgaars fik jeg imidlertid et Brev fra Hørlyck i Rurup, der opfordrede mig til at tilbagekalde Mødet, da han og alle Valgmænlene der fra Egnen dog ikke kunde stemme paa nogen anden end Krüger, fordi denne "uagtet han indrømmede, at han havde billiget, hvad der er skeet, dog udtalte sig paa en saadan Maade, at de goilt kunde mærke, at han helst vilde vælges igjen, og fordi de ikke kunde være med til at vrage deres gramle Repræsentant."

Synes De ikke, jeg har Ret til at være oprørt over en saafan Behandling, er det ikke en skammelig Maade at handle imod en Mand paa, der fuldstændig aabent og ærligt har henvendt sig til Krüger, for, forinden han foretog sig noget, at forvisse sig om, om det var ham med eller imod.

Jeg skal ganske vist rette en indtrængende Opfordring til de Tilstedeværende om at rette sig efter denne Forsamlings Dom, hvilket jeg vil forpligte mig selv til at gjøre, og forresten see at styre alt saa godt, som jeg kan.

Den Erklæring fra Krüger, som i Aftes stod i Dnv., har han unclerskrevet efter min Opfordring. Jeg fik Gustav Johannsen til at rejse ud til ham og havde medgivet ham et Udkast, der Jod meget bestemtere paa, "at han ikke onskede at gjenvælges«, men Johannsen kunde ikke faa ham til at underskrive denne, men maatte nøjes med den, der er fremkommen, og som jo desverre ogsaa er sat paa Skruer.

Vi faar nu see, on saavel vor store Sag som Enigheden i 
vort Parti skal ødelægges blot for at føje en gammel Mands Forfængelighed. Thi det er jo i Virkeligheden det hele. (rud give, at alt maatte løbe godt af.

Efterskr. Det gjør mig hjerteligt ondt, at De ikke vil komme. Jeg kan maaskee trænge til al den Hjælp, jeg kan faae. Bed Deres Broder om at stutte mig af al Magt.

\section{J. P. Junggreen til P. A. Madvig. $\quad$ 5. Aug. 1881. R. A.}

Jeg takker Dem for den Berigtigelse, De gav til Dannevirkes Referat. - - - Jeg veed ikke, hvorledes Bjørnshauge liar det, om det er ligefrem Udygtighed, saa at han ikke har kunnet opfatte, hvad der skete, eller on det er forsætligt, at han fortier Sandheden. I begge Tilfælde er det sorgeligt, at vort vigtigste Blad er i saadanne Hænder. ${ }^{\text {) }}$

Jeg haaber, at Friis-Ejsbøl, til hvem jeg har skrevet strax efter min Hjemkomst, har meddelt Dem Udfaldet af min Mission til Krüger. Han nigtede rentud at tale med mig. Rimeligvis har han været underrettet on mit Komme. Hvad der nu skal skee, ved jeg sandelig ikke. Det er sidste Gang, jeg har sat min Fod i Krügers Hus. - Hvor det er sørgeligt, og hvilken daarlig 'Tjeneste, de gjøre han, der nu smigre hans Forfængelighed, thi nogensomhelst anden Bevæggrund til hans Handlemaade kart jeg ikke see.

Gud give, at vi kunde finde en Ldvei ud af dette Lfore.

\section{J. P. Junggreen til P. A. Madvig. $\quad$ 8. Aug. 1881 . R. A.}

At jeg, efter det, der er foregaaet, fuldstæendig opgiver at ove nogen Indflydelse paa Valget i 1 . Kreds, vil De nok kunne

1) Mødet i Aabenraa refereres foruden i »Dannevirke« urlførligt i "Nationaltidende" (Hiort-Lorenzens Blad), hvis Referat aftrykkes i "I)an.« 8. Aug. - I Mødet deltog 300 Valginæend. Der udspandi sig en lang Diskussion for eller imoll Krüger's (ienopstilling. For Valg af en ny Mand talte foruden Junggreen: (.. Bekker, Hans Lassen, Gustav Johannsen, P. Skau, Holdt (Flenslorg) og F. C. Hansen (Løjtertoft), mod - C. Appel, Rs. Hansen (Kastrup), Physant (Langetved), Mads Jensen (Jægerup), Hørlyck, Tolderlund (Aarup), C. Callsen (Posekjær). Ved Afstemningen var Flertallet for Nyvalg, men Krüger-Tilhængerne nægtede at lade sig tælle. Junggreen tilbyder da at rejse url og tale med Krüger, for at denne i en offentlig Erklæring kan sige, hvad han virkelig onsker. Et aldeles overvejencle Flertal stemmer for at opfordre Junggreen til clette. 
forstaa, og jeg kan ikke andet end raade Dem til at vare forsigtig med, hvad De foretager Dem.

- - Det vigtigste forekommer mig at være, at De benytter den narmeste Fremtid til at satte Dem i Forbindelse med indflydelsesrige Mand $i$ de forskjellige Egne af Valgkredsen, saa vidt muligt af begge Retninger. For Ssulderborg Kredsens Vedkonmende ville Hans Lassen, F. Hansen, Løjtertoft ved Nordborg og slagternester P. Reimers vare tilstrækkelige. De ere de indflydelsesrigeste Mrend paa Als og bo netop temmelig langt fra hinanden, hver i sin Egll af Øen. Vesterfra vilde jeg navnlig tilraade at komme til en Overenskonst n!ed Appel, for hvem rimeligvis Flertallet af hans Meningsfaller boje sig, og som maaske ogsaa er den, der, livis nogen kan det, kan ove Indflỵielse paa Krüger. Helt vesterfra vilde vel Jacobsen i Brøns være en passende Repræsentant. Med et li1le Antal af saadanne Mrnd baade oster- og vesterfra forekommer det mig, De burde holde et Mode i Haderslev for endnu en Gang at forsøge, om der ikke kunde opnaas Enighed. Alsingerne kunne jo godt enten lade e en mode for sig eller indsende en skriftlig Erklaring. Men nødvendigt synes det mig at være, at de forskjellige Retninger ere reprassenterede paa et saadant Mode, og -jeg vilde f. Ex. fra Haderslev By ogsaa inlbyde West, hvis han er hjemme. Er Eenighed mulig, er den jo langt at foretrække for Strid. Skulde der saa ved et saadant Møde rejse sig en $\mathrm{Mu}$ lighed for at opnaa Enighed om at stemme paa mig, men ikk e o m noge n a n de $n$, da vilde det være Uret af mig at modsætte mig, og da skal jeg ogsaa gaa ind derpaa, skjønt jeg med Sandhed kan sige, ugjerne, thi jeg anser mig ikke selv for den lygtigste til d e $n$ Gjerning og lider desuden, som De ved, af en legemlig Svaghed, der undertidèn gjør mig Livet surt nok.

Dette, kjære Dr. Madvig, er min Mening om, hvorledes denne Sag burde gribes an, og skulde der komme et saadant Møde istand, beder jeg Dem forelægge de Tilstedeværende dette Brev.

Min Mening om, at Johanmsen vilde være den bedste Rigs- 
dagsmand for os, er urokket; men d e $n$ vil jo ubetigget være den bedste, om hvem der kan opnaas en Overenskomst.

\section{J. P. Junggreen til Gustav Johannsen. 9 9. Aug. 1881. R. A.}

Jeg fik i Forgaars Breve fra Madvig og Eliassen, der begge paa det indstændigste anmodede mig om at modtage Valg, da de ansee dette for dell eneste mulige Udvej. Madvig vilde strax udstede et Valgopraab, underskrevet af en Del Navne, og Eliassen vilde have mig til at sammenkalde nogle faa Mænd, der saa skulde udsende en skriftlig Opfordring til Valgmændene om at erklære sig for en Kandidat. Jeg har fraraadet begge Dele, jeg selv vil intet have at bestille med at foranstalte noget i 1 . Valgkreds, hvad jeg antager, ingen kan fortænke mig i efter den Erfaring, jeg har gjort. Jeg har derimod tilraadet dem at s:ammenkalde nogle faa Mænd af begge Partier, fra Vester- og Oster (Haderslev)-Amtet og fra Als, og kunne de saa enes om mig, me n ik k o m noge n anden, saa har jeg indvilliget $i$ at tage imod det.

Det har været svært for mig at tage denne Beslutning, thi jeg er ikke vis paa, at jeg er dygtig til d e n Gjerning, og har licesom forhen udtalt, at jeg ansaa dig for bedst skikket dertil, men jeg mente paa den anden Side ikke at kunne forsvare at sige $\mathrm{Nej}$, hvis dette skulde vise sig at være den eneste Udvej.

Jeg skriver dette til dig, kjære Ven. fordi du, hvis noget saadant skulde komme frem, kunde komme paa den Tanke, at jeg ikke havde handlet fuldt ærligt mod dig, hvilket vilde være en stor Sorg for mig. Det kan jo være, at det slet ikke bliver til noget; jeg selv vil blive forbauset derover, hvis Vesterboerne gaa ind derpaa, men skulde det skee, da er jeg alligevel af den Mening, at vi vel bør betænke, om det dog ikke var rigtigst at opstille dig i 2. Valgkreds. Der er vist ingen, der kan samle saa mange Stemmer on sig i Flensborg By og Amt som du, og i det hele forekommer det mig tvivlsomt, om det er rigtigt at concentrere alt paa een Mand. Havde vi nu hele Tiden haft en

1) Eliassen fra Brunsgaard i Langetved. 
sierskilt Kandidat i 2. Kreds, vilde han have været Krügers naturlige Efterfølger, og vi havde rimeligvis været sparet for alle disse Ubehageligheder. Jeg veed ikke, om du har hørt, hvorledes det gik mig hos Krüger. Han nægtede reent ud at tale med ning, og dermed var den Historie forbi. Han er naturligvis strax om Aftenen bleven underrettet om, at jeg kom. Lad mig snart hore lidt fra dig, og modtag en broderlig Hilsen. - - -

\section{J. P. Junggreen til Gustav Johannsen.}

15. Aug. 1881. R. A.

At du kun tog imod Opfordringen til at modtage Valg af (le bedste og reneste Bevæggrunde, derom er jeg fuldstændig overbevist, og naar jeg foreslog dig dertil, saa skete dette ogsaa, som du veed, fordi jeg ansaa dig for bedre skikket dertil end nogen af os andre. Dette har jeg sagt til alle, med hvem jeg har talt derom, og naar jeg - skjønt de Grunde, at hvilke jeg lkke ønskede at opstilles, ere fuldstændig afgjørende for mig selv - alligevel føjede mig efter de fra alle Sider i 1 . Kreds til mig indkomne Opfordringer, saa skete dette kun, fordi alle fremstillede det som den sidste Mulighed for at komme til Enighed. Derom haaber jeg, at ogsaa du er overbevist.

Saaledes stod Sagerne til Løverdag Aften, men saasnart jeg havde læst Hr. Bjørnshauges Referat om Mødet i Vojens, ${ }^{1}$ ) satte jeg mig ned og skrev en Erklæring, hvori jeg udtalte, at jeg efter hvad $d$ e $r$ var bleven udtalt, tog min Indvilligelse til at tage mod Valg tilbage, da jeg ikke vilde opstilles som Kandidat :med en Skavank " (dette Udtryk brugtes jo nemlig on alle os, om hven der kunde være Tale. Det synes, som om Krüger er den eneste Mand i Landet, der ingen Skavanker har).

Denne Erklæring sendte jeg i Gaar Formiddag til Bjørnshauge og forlangte at faa den optaget i Bladet. $\mathrm{Nu}$ er han inidlertid bleven bange, thi i dette Øjeblik modtog jeg et Tele-

1) Rs. Hansen (Kastrup) og J. P. Friis (Ejsbol) har indbudt en snavrere Kreds til et Mode $\mathrm{i}$ Vojens $12 / 8$, hvor det bestemmes, at der skal indledes Forhandling med Alsingerne og derefter muligvis indkaldes til et nyt Aabenraa-Morle. 
gram fra ham om, at han kom præcis Kl. 5. Jeg ved næppe, hvad jeg skal gjore, thi det er dog altfor galt, at de begynde at skjælde mig ud i samme Øjeblik, som de bede nıig on at lade nig valge, fordi jeg synes dem at være den eneste, de kunde enes om. Jeg har stor Lyst til ubetinget at fastholde min Vagring og at lade d'Herrer sejle deres egen Sn. Ja, det er en stor Malheur for os, at Dnv. er kommet i saadanne Hænder. Jeg fortryder kun, at jeg for et Par Dage siclen sendte Bjørnshauge en Artikel. - - - Det var min Mening for Fremtiden at dele ligeligt mellem Flensborg Avis og Dannevirke, men nu kan jeg intet mere have med Dnv. at gjøre.

Ja, hvem skulde have troet, at det skulde gaa saaledes med vort Møde. Efter min Mening var alting forberedt saa goult som muligt, og det vilde ganske vist ogsaa være gaaet godt, naar ikke Forfængelighedens Djævel var faret i Hans Krüger, og naar ikke hans forblindede Tilhængere havde ment, at denne maatte tilfredsstilles, hvorledes det saa end gik med Sagen. Hvilken daarlig Tjeneste, de gør ham, og hvilken sorgelig Slutning paa en saadan Lobebane som hans.

som jeg allerede har skrevet til dig, ønsker jeg ogsaa, at. clu skal opstilles som vor Kandidat i 2 . Valgkreds, og der maa jo i demme Henseende træffes nogle Forberedelser. Dog mener jeg, let ikke haster saa stærkt dermed. Maaske kunde vi vente til Hosten. - - - At vælge paa Krüger i 2 . Kreds vil jeg bestemt modsatte mig. _ - Det er sørgelige Forhold. Vor. herre hjælpe os.

Efterskrift: I Aftes var Bjørnshauge hos mig og bad nig saa lapıge, at jeg tog nin Erklæring tilbage. Han var i stor Vaan(ie. Ogsaa Jacobsen fra Brøns og en Mand fra Rejsby var her for at opfordre mig til at indkalde en ny Forsamling. Dette nagtede jeg, med mindre en 7 a 8 andre gode Mænd fra Landets forskellige Egne vilde sæette deres Navne med under. Derfor vilde de nu sørge. Sker det, maa jeg vel sætte dit Navn med. Alene giver jeg nig ikke mere af dermed. Her i 2. Kreds skulle vi let blive enige. 
- $\quad$ - Du har jo vist lest det udførlige Referat om Mrsdet, der har staaet i Nationaltidende. Det var i det væsentlige correct, og jeg antager næppe, at nogen har kunnet faa anlet Indtryk deraf, end at vore Modstanderes eneste Argument i Virkeligheden var, at Krüger vilde vælges, og derfor burde det skee. Er det ikke surgeligt, at det skulde tage den Ende med lenne Mand, at han sætter Tilfredsstillelsen af sin egen Forfængelighed over ethvertsomhelst Hensyn til Sagell. Thi saaledes er det. En simpel Erklæring fra liam om, at han ikke vilde vælges, vilde have bragt alle Grundtvigianere og Venstremænd (thi ogsaa af dette stikker der noget deri) til Fornuft, og saa var vi nok blevne enige om en anden Kandidat. Men en saadan vil han ikke udstede, og hans Tilhengere, der vare komne liertil i den Tro, at de var en stor Majoritet, blev helt ustyrlige, da de saa, at de kun vare en Minoritet. De nægtede da reent ud at foje sig efter Flertallets Beslutninger, og derfor afbrodes Modet paa dette Standpunkt for dog ikke at udelukke Muligheden af en Overenskomst. Jeg fik jo saa det mindre behagelige Hverv Dagen efter at rejse ud til Krüger for at faa ham til at afgive en bestemt of fe $\mathrm{ntlig}$ Erklæring om, hvad han vilıle, hvorefter vi saa vilie have føjet os. Det eneste Svar, han gav mig, var: Jeg ansker ikke at tale med nogen, hvorefter han vendte sig fra mig (han laa $\mathrm{i}$ Sengen). Saa gik jeg, thi jeg vilde ikke tigge nig paa ham, men jeg saa deraf to Ting, for det første, at han betragter Sagen fra et reent personligt standpunkt, og dernæst, at han endnu samme Aften som Modet var bleven afholdt, var bleven instrueret. Saa har her senere varet en stor Masse Mennesker, og jeg faar hver Dag ell Masse Breve, der alle gaa ud paa at opfordre mig til at lade mig velge. Deri har jeg da ogsaa, skjønt jeg kan sige med tungt Hjerte, indvilliget, og det bliver bestemt Enden paa Historien. -

i) Den konservative Politiker Godsejer Villars Lunn l)lev i $1 \times \times 1$ wift med Junggreens Iatter Kathrine. 
J. P. Junggreen til P. A. Madvig.

27. Sept. 1881. R. A.

Det gjør mig hjerteligt ondt, men jeg kan ikke føje Den. At blive opstillet som Candidat med et stort Parti imod sig er, saaledes som vore Forhold ere, en utaalelig Stilling.) Væl ${ }^{2}$ overbevist om, at den tjener Sagen bedst, der for Enighedens Skyld træder tilbage, og dette skal ogsaa nok længere hen blive erkjendt. Jeg har ikke i Sinde at trække mig tilbage fra det politiske Liv. Jeg vil blive ved at arbejde paa at opretholde Sproget, Nationaliteten og Modet og Haabet for vort Folk, og saa kan maaske endnu den Tid komme, da man indseer, at maur har gjort mig Uret.

\section{J. P. Junggreen til Gustav Johannsen.}

28. Sept. 1881. R. A.

Af en Erklæring, som du i Aften vil se i Dannevirke, vil du see, at jeg endelig er bleven kjeed af disse Historier. Jeg har sagt Hr. Poulsen ${ }^{1}$ ) og Cons. Sandheden og erklæret, at jeg ikke vil vælges. Den Mand, der kun vælges af et Parti blandt Folket, er efter min Mening saa uheldig stillet, at jeg for ingen Pris vil modtage denne Post, og af Folk, der behandle Facta paa den Maade som mine Fjender, kan man jo vente sig alt. Tak for de Ord, du i Dag bragte om mig i dit Blad. Det er dog godt, at der er enkelte Folk, der kunne see Sandheden, og have Mod til at sige den. Hvad siger du til saadan en "Præst« som L. B. Poulsen! $\left.!^{1}\right) \ldots$

1) Krüger dør d. 27. Aug., uden at der paa dette Tidspunkt er kommen Klaring paa Spørgsmaalet om Stillingen til Rigsdagsvalget. $\mathrm{Nu}$ indbydes Valgmændene i Haderslev Kreds til Møde $i$ Vojens 17. Sept. Ved dette Møde, hvor ogsaa 37 tyske Valgmænd er mødt op paa Grund af en mindre klar affattet Indbydelse, stemmer 92 paa Junggreen til Krügers Afløser, 22 på Hans Lassen, 3 Stemmer er spredt og 20 stemmer ikke. - 20 Sept. holder Sønderborg Kreds Møde i Sønderborg, hvor Hans Lassen faar 55, Junggreen $13 \mathrm{St}$ - - D. 28. Sept. erklærer Junggreen, at han ikke vil tage morl Valg. "Af et Parti af mine Landsmænd vil jeg ikke vælges«.

1) Junggreen er navnlig bitter paa Frimenighedspræst L. B. Poulsen for hans Udtalelser i Vojens $17 / 9$., hvor han bl. a. har sagt, wat Junggreens Færd med $H$. Krüger paa det sidste har været os en Forargelse, thi det er jo vitterligt, at Krüger paa det sidste viste ham bort $\ll$. 


\section{J. P. Junggreen til Gustav Johannsen. 11. Okt. 1881 R. A.}

-- - Nu i Aften er der jo ogsaa et Opraab i Dannevirke oin at stemme paa mig. $\left.{ }^{j}\right)$ Jeg vilde onske, at det ikke var sket, og jeg var i Fredags i Haderslev for om muligt at forhindre. det, men det var umuligt. Vedkommende erklærede mig ligefrem, at jeg jo kunde gjøre, hvad jeg vilde, men at jeg ikke kunde forbyde dem at stemme paa mig, hvad jo ganske vist erTilfældet. Hvad skal Enden blive?

Jeg vil forholde mig fuldstændig passiv og lade Tingene gaa, som de kunne, thi jeg ved i Sandhed ikke, hvad jeg mere kan gjore derved - -

\section{J. P. Junggreen til P. A. Madvig. $\quad$ 1. Nov. 1881. R. A.}

(ang. en Endring til en Erklæring i Dnv.) Lad os nu af vore Hjerter banlyse Uviljen imod Lassen.') Han skal jo nu være vor Rigsdagsmand, og jeg synes saa, det maa være bittert nok for ham at modtage et Valg, der er tilvejebragt med saadanne Midler. Derimod skal jeg aldrig glemme de Herrer, der i Haderslev Amt have arbejilet for ham, hvad de have gjort. De have tydeligt vist, at for dem er Sagen intet, men Partiinteresser alt, og den Maade, hvorpaa de ere traadte op imod mig. er en stor Skam for dem selv.

\section{J. P. Junggreen til Gustav Johannsen. 15. Nov. 1881. R. A.}

- - - Det er Aar siden, jeg har set Folk saa glade"; _- - Du undskylder nok, at jeg trods min "Mangel paa

1) 8. Okt. har en starre Kreds af Mand opfordret til at stemmepar Hans Lassen. 11. Okt. kommer Opfordringen til at stemme paa Junggreen. - Ved Valget fik Junggreen i Haderslev Ant $3743 \mathrm{St}$... Hans Lassen 1698, men i Sønderborg Amt fik Junggreen kun 93 mod Hans Lassens 3530 . Den tyske Kandidat fik samtidigt i hele Kredsen 2515 St., saa ingen af Kandidaterne havde naaet absolut Majoritet, og Omvalg mellern Hans Lassen og Junggreen skulde saaledes finde Sted.

2) 2. Nov. opfordrer Junggreen i "Dannevirke" alle Vælgere til at stemme paa Hans Lassen. "Der har aldrig været noget Uvenskab. mellem Hans Lassen og mig, om end vore Anskuelser paa et enkelt Punkt som bekendt er meget forskellige«. - Hans Lassen valges da 7/11. med 8004 St.

3) I Anledning af Gustav Johannsens Valg ved Omvalget i 2 . hreds. Junggreen har verl et Gaasegille paa Hotel Danmark oplasst T'elegrammet orn Valget. 
parlamentarisk Erfaring«, om hvilken der jo har været skrevet en hel Del, tillader mig at give dig et Raal, som ialfald er godt ment.

Er det muligt, saa maa du see at komme til Orde snarest muligt, ialfald i denne samling. Skulde Rigsdagen blive opIast, vil dette være en stor Hjælp for os, naar vi skulle have dig valgt jgjen. Du er jo godt skaaret for Tungebaandet, og tilby der der sig intet andet, saa forlang Ordet under Forhandlingen on Budgettet. Og du maa om muligt berøre alle de Spørgsunaal, som sætter sindene i Bevagelse i denne Tid. - - - -

Trykt i Hejmolal 13/8. 192\%.

Min kare unge Landsmand.

Det skal vare mig en Glade at besvare Deres Spurgsmaal, der vidner om, at De føler varmt for vort lolks store Fællessag.

sporgsmaalet on at understotte den danske Presse her i Laudet har, straks da vi stiftede Foreningen, været en af de Ting, vi tirnkte paa, og som vi underkastede den omhyggeligste Overvejelse. V'i har imillertid mattet opgive denne Tanke, fordi der til at virkeliggore den fordres langt storre Midler, end vi kan tilvejebringe. "Dannevirke" har, saa vidt jeg ved, rigelig 2000 Abonnenter, »Flensborg Avis« henimod 1000, og "Dybbolposten " ontrent 500, altsaa i det hele 3500. snarere over end under. Tanker man sig nu en I'nderstøttelse, der skulde $\therefore æ$ tte disse Blade i Stand til at nedswette Prisen med $50 \mathrm{Pf}$. for Kvartalet, hvilket vilde være det mindste, der kunde være Tale on, saa vilde dertil udfordres 7000 Mk. aarlig. Sprogforeningens Indtagter i Fjor var rigelig 5000 Mk. og vil i Aar, som Følge af at vi har maattet nedsætte Bidraget fra 5 til 2 Mk., rimeligvis blive betydelig mindre. Hvis vi altsaa gav hele vor Indtagt til dette Brug, vilde dette næppe kunne bevirke mere, end at Prisen kunde blive nedsat med 25 Pf. on Fjerdingaaret, noget, der næppe vilde have stor-Betyduing for Bladenes 
Udbredelse. Derfor har vi maattet opgive denne Tanke og indskrænke os til at forsyne Folket med god dansk Læsning ved Oprettelsen af mindre Biblioteker. Af saadanne har vi oprettet $80 \mathrm{og}$ har til nu uddelt over 8000 Bind gode danske Bøger og 4000 Eksemplarer af en dansk Sangbog. De vil deraf se, at det ikke er nogen ringe Virksomhed, vi har udfoldet. Vi vilde urrlig have nedsat Bidraget, nen det var ligefrem Hensyn til Befolkningen i de nordligste Distrikter, Rødding, Københoved etc., der tvang os dertil, da der derfra lad uafladelige Klager over Bidragets Størrelse, og man vilde endog have haft det nedsat til 1 Mk. aarlig.

Hvad Deres andet Sporgsmaal angaar om Sammenlægning af "Dybbol-Posten " med "Flensborg Avis«, da tror jeg ikke, del" er en eneste Mand her i Landet, der vilde anbefale en saadan. At "Freja" ophørte at bestaa som selvstændigt Blad, har været til Skade for den danske Sag her i Egnen. Det har derved mistet mange af sin Abonnenter, fordi et Blad, der udgaar i en anden By, ikke er i Stand til at behandle de lokale Forhold saaledes som det forlanges af en stor Del af Abonnenterne. Jeg vilile derfor aldrig kunne tilraade, at det samme Eksperiment foretoges med "Dybbølposten «.

"Folkebladet" er for Resten her i Egnen for en stor Del blevet fortrængt af et lille billigt dansk Blad "Hejmdal«, der ulgaar her i Byen, og havde vi beholdt "Freja" her, vilde det aldrig have faaet Indpas iblandt den danske Befolkning. Til Slutning vil jeg endnu en Gang udtale, hvor glad jeg blev over Deres Brev, og forbliver med venlig Hilsen

Deres ærbørlige

J. P. Junggreen.

\section{J. P. Junggreen til Villars Lunn.}

22. Febr. 188:2. Privateje.

I Hast disse faa Ord! Tro ikke, at jeg billiger alle disse haarde Idtalelser om Lassen. ${ }^{1}$ ) Folk vidste godt, hvad han

1) Hans Lassen har aflagt Landhagseden. 
vilde, og han har ikke bedraget nogen. Men da hans Mandat er udløbet til Efteraaret, burde han have afventet Resultaterne af de nye Valg.

Og Gud veed, det seer sort ud, for Jer og for os, men dog ville vi ikke fortvivle. Kun undertiden kommer der en Stemning over mig, hvor jeg seer alt sort i sort. Jeg har, som du siger, oplevet alt for mange Skuffelser. - - -

J. P. Junggreen til Moller Jacobsen. 27. April 1882. Privateje.

Tak for den indsendte Liste. Det er glædeligt, at der dog er saa mange Medlemmer i Brøns Sogn. Det er ikke mange Steder, vi har saa mange.

- - - Hvad Salmebogssagen angaar, $\left.{ }^{1}\right)$ da har det Udvalg, der er bleven nedsat af de forskjellige synoder, i forrige Uge været samlet her i Byen og vedtaget at foreslaa de i $\mathrm{Maj}$ og Juni sammentrædende Synoder, at der udgives et Tillæg af de bedre og nyere danske Salmer, som saa kunde bruges ved Siden af de existerende Salmebøger, indtil der kan tilvejebringes en ny. Samtidig vedtoges det at udtale, at Valentiners Samling ikke ansaaes for skikket til almindelig Indførelse. Dette synes mig dog ikke at være et saa ganske ringe Resultat.

Det glæder mig, at Sangbogen') har gjort Lykke. Af den er der uddelt henimod 4000 Exemplarer, og dermed haaber jeg, at der er sket lidt for at opretholde det danske sindelag hos vort Folk.

Og saa er jeg dybt bedrøvet over den hele Stilling, og skal det blive ved paa denne Maade, frygter jeg for at vi gaar til Grunde. Hele den Maade, hvorpaa vi nu optræde, giver os jo mere og mere Characteren af et almindeligt preussisk Opposi-

1) Siden 1879 har der været Uro om Salmebogsspørgsmaalet, der llev drøftet baade i Pressen og ved Synoderne. Provst Valentin i GI. Haderslev havde udgivet dels "Vor Kirkes yndigste og lifligste Kjærne-Salmer“ (1869) og 1875 en Bearbejdelse af Pontoppidans Salmehog. I 1883 nedsattes en Salmebogskommission, hvis Arbejde satte Frugt i "Evangelisk-luthersk Salmehog for dansktalende Menigheder، (1889).

*) Sanghogen o: Lohmanns: Dansk Sanghog. 
tionsparti, og vi burde indtage en anden Stilling. Hvad vi end sige og gjøre i Rigsdagen og Landdagen, saa ville vi aldrig kunne bevirke, at Regjeringen standser med sine Fortyskningsbestræbelser. Disse ere fra deres Standpunkt fuldstændig logiske og rigtige, og hvad vi havde at gjøre, vilde efter min Mening være at opretholde Protesten imod Adskillelsen fra Danmark i dens allerskarpeste Form, og samtidigt med forenede Kræfter af al Magt at arbejde paa at opretholde Sproget og det danske Sindelag hos vort Folk. Hvad der saa vilde komme ud deraf, ja det kan ingen vide, mell vi holde dog altid Muligheden for en Restitution aaben, hvorimod vi paa den nuværende Vej kun komme stadigt dybere og dybere ind $i$ det preussiske Væsen og paa en Maade selv anerkjende Stillingen. Dog dette er jo, som det er, og vi maa nu tage Folgerne.

(J. vil besøge J., naar han i Juni kommer vestpaa). I de sidste 2 Aar har min Son rejst. Jeg er jo ikke saa meget stærk og har gjort mange Rejser. der har været drøje nok. Træffer man det med daarligt Vejr, kan det være meget ubehageligt saaledes at kjøre omkring i 4 a 5 Dage paa en aaben Vogn. Forhen har jeg ikke agtet derpaa, men nu maa jeg tage mig noget mere iagt. Jeg skulde gjerne leve nogle Aar endnu for mine mange Børns skyld.

\section{J. P. Junggreen tiil Gustav Johannsen.}

2. Maj 1882. R. A.

Bachmann var i Aftes hos nig med et Brev, hvoraf jeg kan see, at han har anmodet dig om at forebringe Sagen om de Udvandredes Stilling i Rigsdagen. Hvorvidt det er muligt for dig at gjøre dette, derom kan jeg jo ingen Mening have, men uagtet jeg aldeles ikke venter, at du i Realiteten kan udrette noget for dem, saa saa jeg dog gjerne, at du gjorde det, hvis du kan. Thi der er intet andet, der vil gjøre dig saa populær iblandt Folket som netop det, at du tager dig af denne Sag, der jo berører saa mange. Og jeg ønsker meget, at du skal blive afholdt af Folket. 
Derimod deler jeg fuldstændig dine Betænkeligheder ved at motivere Sagen paa den af Bachmann foreslaaede Maade. Vi maa paa ingen Maade gjøre eller sige noget, der kan udtydes, som om vi ansaa Sagen for afsluttet. Der er desværre allerede skeet for meget i den Retning.

Kunde det ikke gaa an at bære sig saaledes ad, hvis du i det hele kan faa Sagen frem: efter først at have skildret de Udvandredes pinlige Stilling og Befolkningens danske Sindelag da at fortsætte saaledes: kan det nu, mine Herrer, undre Dem. at en Befolkning der tænker saaledes og hvem en snarlig Gjenforening med det Folk, hvortil dens bedste og varmeste Følelser drager dem, var stillet i Udsigt, foretrak at gaa til Danmark fremfor at tjene det Land, fra hvilket den var fuldt berettiget til at vente, at den snart vilde blive skilt igjen. Var der noget unaturligt i dette, og tror De ikke, mine Herrer, at under lignende Forhold vilde Flertallet af Deres Vælgere have gjort det samme? Grib dog i Deres egen Barm og tænk Dem, med hvilke Følelser en patriotisk Preusser i sin Tid i 1807 maa være traadt ind $i$ den westphalske Armee. Fortjener et Folk under saadanne Omstændigheder, at man tager andre Hensyn end under almindelige Forhold? Thi saaledes, mine Herrer, var Forholdene hos os. Folket ventede og var fuldt berettiget til at vente, at Spørgsmaalet om det vilde høre til Preussen eller til Danmark vilde blive fremstillet til dets egen Afgjørelse, og det vidste ogsaa, hvad Resultatet vilde blive, nemlig at den langt overvejende Majoritet vilde stemme for Gjenforening med det gamle Fædreland, hvilket for Resten ogsaa vilde være Tilfældet den Dag i Dag. Thi det kan jeg sige med Sandhed: vi har intet højere Ønske.»

Saaledes. kjære Ven, mener jeg, at du kunde motivere Sagen. Dermed indrømmes intet, og du kan maaske endog faa Lejlighed til at give Hr. v. Bismarck nogle alvorlige Hib. Om det nu lader sig gjøre eller ej, derom kan jeg ingen Mening have. ${ }^{1}$ )

1) D. 22. Maj 1882 interpellerer Gustav Johannsen om nordslesvigske Optanters Genoptagelse i Statsforbundet. 


\section{J. P. Junggreen til Gustav Johannsen.}

4. Aug. 18\%:2. R. A.

(Valgmandsvalg). Ieg arbejder ihærdigt paa at faa den ulykkelige Strid, der hersker imellem os, bilagt, men om jeg udretter noget, er vist tvivlsomt. Men saa vil jeg dog $\mathrm{i}$ det mindste see at bringe Enighed tilveje her i 2 . Kreds, saaledes at alle Valgmand stemme paa den, der viser sig at have Flertallet for sig.

Jeg har jo, som du har set, stillet mig ganske upartisk til Sagen, thi om jeg end selv langt vilde foretrakke, at vi nagte(le at aflagge Ed, saa anser jeg clog langtfra vor Optræden i Landdagen for at vare af saa afgjwrende Betydning, at jeg for den Sags skyld vilde sxtte Enigheden og Sammenholdet par spil, og de, der blot for at satte deres egen Mening igjennem ikke tage i Betænkning at splitte vort Folk i to fjenctllige Lejre. gor i Sandhed kun sagen en daarlig Tjeneste. - Hils $\mathbf{H r}$. . Tessen, $\left.{ }^{1}\right)$ der i Sandhed er en dygtig ung Mand.

\section{J. P. Junggreen til Gustav Johannsen. 14. Aug. 188:2. R. A.}

- - - - Det gjorde mig lidt ondt, at du taler til mig om Stridighederne som E d e r s Strid om Edssporgsmaalet. Jeg selv var af den Mening, at jeg mere end nogen anden har arbejdet for at faa denne Strid bragt ned og atter at samle Folket $i$ Fnighed. - - - Jeg er meget hedrøvet over Tilstandene, thi skal denne Uenighed blive ved, saa seer jeg intet andet end Undergang for Øjnene. - - -

\section{J. P. Junggreen til P. A. Madvig. $\quad$ 6. Okt. 1882. R. A.}

(Et Forslag om et Møde for at naa til Enighed mellem Partierne). Hvis Hans Lassen indbyder mig til at være tilstede, skal jeg naturligvis gjerne møde, men jeg tvivler derom, da han jo godt ved, at jeg i demne Sag er hans Modstander. Jeg henstiller dog til Dem, om det ikke maatte være hensigtsmæssigt, at De og Hörlyck medtog en anden i Amorsens Sted. Efter

1) Jens Jessen, der den 1. Juli 18k2 har overtaget Redaktionen af "Flensborg Avis«. 
de heftige Uditalelser, der med Navns Underskrift ere vexlede imellem de to, $\left.{ }^{1}\right)$ kan det næppe ventes, at de ere saaledes stemte, som det maa anses for hensigtsmæssigt, naar en Overenskomst skal komme istand. Der maa vel kunne findes en intelligent Mand, der staar paa vort Standpunkt uden netop ved stærke offentlige Udtalelser at have ægget Modpartiet. Det gjælder jo kun om at vedtage en Erklæring om, at man vil bøje sig for Majoriteten, samt at forhandle om Maaden, hvorpaa en Fællesudtalelse fra samtlige Valgmænd kan bringes tilveje. Selve Sagen er uddebatteret, og ny Drøftelse vil kun irritere.

Jeg ved ikke, hvad De har tænkt om de danske Valgmænd fra 4. Kreds (eller er det 3.? - dem fra Møgeltønder, Ballum etc.) For mig har altid det danske Slesvig staaet som en Helhed. og mig forekommer det urigtigt at udelukke en Deel fra Afgjorelsen, der kunne blive bestemmende for hele vor fremtidige Stilling - kun fordi Regjeringen i sin Interesse har skilt dem fra os og slaaet dem sammen med et tysk Flertal. Men det beror jo naturligvis paa Indbyderne. - - -

Om Udfaldet af selv V'algmændenes Votum troer jeg bestemt, at det vil gaa i Retning af Edsnægtelse, forudsat at Stemningen i Haderslev Østeramt har undergaaet en saadan Forandring, som De antager. Skulde de 70 Valgmænd, der sidst stemte paa P. Skau, atter ville stemme for Edsaflæggelse, saa stiller Sagen sig naturligvis anderledes. Af Aabenraa Amts Valgmænd ville, efter hvad jeg veed, det overvejende Flertal stemme for Edsnægtelse, hvorimod Als og Sundeved vistnok med ganske faa Undtagelser stemme imod. Gud give nu, at det maa lykkes at tilvejebringe Enighed.

1) Da Hans Lassen aflagde Eden, var Konsul Amorsen blandt hans voldsomste Angribere. Bl. a. havde han (Dnv. 4/2. 82) skrevet, at Hans Lassen ved dette Skridt havde "tilføjet vor Livssag et af de tungeste, maaske det tungeste Slag, der endnu er blevet ført imod flen«. - Om Brydningerne omkring Landdagsvalget 1882 henvises til Sunclerjyllands Historie V- S. $159 \mathrm{f}$. 
- - - - Jeg har faaet en Del Exemplarer af Hörlycks og H. Lassens Opfordring til Valgmændene tilsendt fra sidstnævnte, der tillige underrettede mig om, at han ikke troede, at Befolkuingen i hans Egn vilde bøje sig for en saadan Afgjørelse, hvis den gik den imod, og det samme har jeg hørt baade nord- og vesterfra. Skulde dette stadfæste sig, ere vi virkeligt komne saa vidt, at vi aldeles ikke mere kunne enes om noget, da forekommer det mig ørkesløst at arbejde videre for den danske Sag her i Landet. Vi ere da modne til undergang og fortjener intet bedre, og det forekommer mig at være Daarskab at slide sig op for en sag, som Folket selv med vold og Magt slelægger. Give Gud, det maatte komme anderledes.

\section{J. P. Junggreen til Gustav Johannsen. 11. Okt. 1882. R. A.}

- - - Jeg er meget bedrøvet over den Vending, Forsøget paa at bringe Enighed tilveje tager. Der er ingen ærlig Vilje paa nogen af Siderne, og saa kan sligt jo ikke gaa. Allerede for 8 Dage siden havde jeg Brev fra Hans Lassell, hvori han ammodede mig om at arbejde for Edsaflæggelsen, da han ikke troede, at Befolkningen i hans Egn vilde bøje sig. Jeg finder denne Anmodning til mig noget uforskammet, thi man kan dog ikke arbejde lige imod sin Overbevisning, og jeg finder det $i$ df t hele $i$ dette Øjeblik urigtigt at agitere for den ene eller den anden Anskuelse. Hvad jeg har sagt og skrevet til dem, jeg har haft nied at gøre, er dette: "Besvar det fremsatte Spørgsmaal efter eders Overbevisning om, hvad der tjener Sagen bedst, men skulde det vise sig, at Flertallet er paa den anden Side, saa bojer eder. Hovedsagen er, at vi blive enige, og jeg anser det for enhver dansk Mands Pligt at arbejde hen til dette Maal«. Det er den Agitation, jeg har drevet, og den tror jeg nok, jeg kan forsvare. - Derimod tror jeg hverken, at $\mathrm{H}$. Lassen eller hans fordums Venner og nuværende Modstandere har arbejdet a r lig t for Sagen, og derfcr kommer der næppe noget ud af den. - Nu faar den vel gaa sin Gang. I alt Fald kunne jo 
kun Lassen og Hörlyck standse den. Hvis Valgmændene i 4 . Kreds ikke ville deltage i denne Afgorelse, hvad jeg synes vilde have været rigtigt, mener jeg, det var bedst, om heller ikke de Valgmænd, der vælges i Eders (Flensborg) Kreds, gør det. -- Jer kommer jo forresten som sagt næppe noget ud deraf, thi jeg ser jo, at ogsaa d'Herrer Arnum, Poulsen \& Co. ${ }^{1}$ ) ere paa Spil. De Herrer synes at være villige til at arbejde for alt muligt, for Hans Lassen og imod Hans Lassen, kun ikke for Enighed og Sammenslutning.

Jeg synes godt om, at Valgmændene i 4. Kreds stemme paa dig. Det er et Livstegn fra den Egn, og et saadant er altid godt. Men naar du nu kommer derud, kjære Ven, saa bliv ved den samme Fremgangsmaade, som du har fulgt hidtil, optraed ikke som Edsuægter eller Edsaflægger, mell simpelthen son delr d a n ske Kandidat for 4. Valgkreds, og lad dem see at samle saa mange Stemmer paa dig som muligt. Det kan efter min Mening slet intet gavne, at du tager Parti for en af de Herrer H. eller H. L., men kun gore dig $m$ in dre velset for en Del af de Vælgere, vi skal have til at stemme paa dig ved næste Valg. ---

\section{J. P. Junggreen til Villars Lunn.}

22. Okt. 1882. Privateje. gaar igjennem dit Brev, men du skal ikke tage dig det altfor nær for min skyld. Trods mine $55 \mathrm{Aar}$ er jeg endnu i Besiddelse af tilstrækkelig aandelig Elasticitet til ikke at lade mig trykke til Jorden af saadanne Ting. Da jeg gik fra Ti etge n, var jeg meget nedslaaet, men da jeg gik fra Jacobsen jun. ${ }^{2}$ ) var jeg nærved at lee ad mig selv, fordi jeg havde været naiv nok til at tro, at de Herrer vilde aabne deres store Punge, fordi jeg bad dem derom.

Jeg har haft meget at gjøre i Anledning af (let nu overstaaede Valgmandsvalg. Jeg har holdt Møder og skrevet Avis-

1) Gdr, Laust Arnum og Frimenighedspræst L. B. Poulsen, legge fia Bovlund.

") Brygger Jacobsen. 
artikler, men har jo da ogsaa haft den Tilfredsstillelse, at alt er gaaet fortræffeligt. (Stillingen hævdet). Nu har jeg kun clen sorg med Forholdet til Hans Lassen, som har baaret sig daarligt ad; og nu rakke de ham igjen ned fra alle Kanter, hvilket kun gjør ondt værre. Thi vi ville dog komme til at vælge ham paa Graasten, uagtet han næsten ingen Stemmer har blandt Valgmændene i Aabenraa Amt. Vi kunne jkke indlade os paa en Valgkamp imellem de danske Valgmænd i :. Valgkreds; det bliver den rene Ødelæggelse, hvis det skal blive ved med denne Opæggelse og Udsaaen af Bitterhed imellem den danske Befolkning. Dr. Madvig og Amorsen, der ere Hans Lassens bitre Fjender, begyndte allerede i Gaar med en meget spydig Udtalelse i Dannevirke, hvilket strax i Aftes foranledigede mig ti] at skrive en lille Artikel for om muligt at sætte en stopper for dette Vasen. Men maaske opnaar jeg intet andet derned, end at de give sig til at skjælde mig ud fra alle Sider. Det er ikke forste Gang. - - - -

J. P. Junggreen til P. A. Madvig. udateret (omkr. 5. Nov. 1882).

Jeg skrev det lille Stykke i Damnevirke efter at have last Deres og Amorsens Udtalelse on Hans Lassen. Det er umuligt at forhindre, at han bliver valgt paa Graasten i Morgen, og det er bedst nu at lade demne Sag gaa rolig frem.

Alsingerne og Sundeved'erne holde fast ved ham, og en yderligere Debat om hans Holdning vil kun forbitre dem, som vi dog ikke maa stode fra os. Det er ganske vist sørgeligt med hans uklare Udtalelser og vaklende Holdning, men L. Arnum \& Co.s Erklæring kall lige saa lidt billiges. Naar man har været med til, uden Indsigelse at modtage en saadan Overenskomst, er det Uret faa Dage efter at give sig til at agitere imod, at der kan komme noget ud af den.

Hans Lassen var her i Mandags med alle Erklæringer fra Als og Sundeved, naturligvis underskrevet i hans Faveur, han var af den Mening, at han aldeles ikke lavde sagt sig los fra Overenskomsten ved sit Brev til Hörlyck, som han visselig saa 
hellere maatte have ladet være at skrive. Det hele forte naturligvis til intet. Indsendelsen af Erklæringerne fra Aabenraa Amt var standset ved Hörlycks Udtalelse. Der var indkommet 48, hvoraf 34 imod og 14 for Edsaflæggelsen. Var de alle komne, antager jeg, der vilde have været omtrent 50 imod og 20 for. - Gud være lovet, at det gik godt med Valgene, jeg frygtede ineget for dem.

\section{J. P. Junggreen til Villars Lunn.}

22. Marts 1883. Privateje.

- - Jeg seer, at min Ven P. Skau i denne Tid holder Foredrag om den nationale Sag i de forskjellige Foreninger i Kjøbenhavn, ogsaa for Socialisterne og for Studentersamfundet. Det er i Sandhed en fortjenstfuld Virksomhed af ham, saa meget mere som han selv er een af dem, der herhjenıme har lidt en ilde Medfart af vore ultragrundtvigianske Venstremand. De have vraget ham ved alle Lejligheder, hvor der har været Tale om at vælge ham til nogen offentlig Bestilling, og dog staar han med Hensyn til god Villie lige saa højt og med Hensyn til Dygtighed hojere end Flertallet af dem, der er bleven foretrukket for ham, og han er i Besiddelse af en naturlig Veltalenhed, der gjør, at hall. til Trods for de Mangler, han, som vi alle, har, er langt bedre skikket end de fleste andre til at føre Folkets Sag, hvor det skal skee ved mundtlig Forhandling. Dertil er han velmenende og bilder sig ikke ind selv at have slugt al Verdens Visdom. -

\section{J. P. Junggreen til Villars Lunn.}

Sommeren 1883. Privateje.

Tak for din Indbydelse, men jeg kommer ikke over til Eders Møde. At jeg i højeste Grad misbilliger Eders forrykte Venstrepolitikeres Færd, samt at jeg baade mundtligt og skriftligt udtaler denne Misbilligelse, veed du jo nok, men jeg tror ikke, det vilde være rigtigt, om jeg for bestemt optraadte som Partimand, som det vilde blive Tilfældet, hvis jeg deeltog i dette Møde. Det vilde kun have til Følge, at ogsaa Venstre fik nogle af sine Tilhængere herovrefra til at optræde ved sine Møder, og 
det vilde næppe gjøre Gavn, hverken for (os) eller for Eder. En anden Sag er det, naar jeg indbydes til et almindeligt Folkemøde. Der har jeg jo et Par Gange givet Møde og ikke skaanet de Tilstedeværende, men klart og tydeligt sagt dem, hvor taaleeligt og ligefrem uforsvarligt det danske Folk opfører sig.

Den skandinaviske Stamme synes mig at staa lavest $i$ politisk Henseende af alle europæiske Folk. Ingen anden Folkestamme lader sig saaledes bedaare af Fraser og tomme Ord som den. - - Ja, jeg bliver bitter hver Gang, jeg tænker derpaa. - - - Hils Ploug fra mig, ham holder jeg rigtig meget af.

J. P. Junggreen til Meller Jacobsen. 22. Juni 1883. Privateje.

- - Det blev jo ikke til noget med Ryslingemødet, ${ }^{1}$ ) og jeg var glad derved, thi jeg har kun lidt Lyst til at deltage $i$ sligt - og dog kommer jeg den 6. Juli til at deltage i et Møde paa Vindinge Højskole ved Vejle. Rosendal bad mig forleden, da jeg traf sammen med ham, indstæendig om at komme, og jeg lovede det. Jeg har dog kun een Ting at sige Folket derovre, og det er, at de handle uforsvarligt og taabeligt ved at ode al deres Kraft paa Strid og Splid om ligegyldige Ting og forsømme det ene nødvendige at sætte Landets Forsvarsvæsen i saadan Stand, at de næste Gang kunne kæmpe med et rimeligt Haab om ikke at staa til skamme, at frelse Landet eller at falde med Ere. Dette ville de faa at hore af mig allevegne, hvor jeg kommer, og det er mig ligegyldigt, hvad enten de blive vrede eller milde derfor. Jeg bejler ikke til Folkegunst.

Sprogforeningens Generalforsamling gik meget godt, og jeg heklager kun, at ikke flere danske Mænd benyttede denne Lejlighed til en Gang at komme sammen med Ligesindede. Det er dog en Opmuntring $\mathrm{i}$ denne sørgelige Tid. - - - -

\section{J. P. Junggreen til Villars Lunn.}

19. Oktober 1883. Privateje.

- _ - Ja, kjære Villars, Livet uden Dore er fuld af Skuf-

1) Dev har varet planlagt et lignende Morte i Ryslinge som det tioligere omtalte. 
felser og brudte Illusioner, og lykkelig den der som du har et lykkeligt Hjem og en kjærlig Ledsager paa Livets Vej. - - I dette huslige Forhold ligger Livets sande Lykke. Resten har man for det meste kun Sorger og Bekymringer af, især naar mall ikke kan stille sig ligegyldig overfor sit Folks Skjæbne, men sorger over dets Ulykke og dets Misgreb - Demme Betragtning af Forholdene er gammel hos mig, og mange, mange Gange har jeg besluttet at lade de offentlige Forhold gaa deres skjæve Gang, men jeg kan det ikke; naar den Uret, der øves her i Landet, gaar over visse Grænser, saa kommer mit Blod i Kog, og saa glemmer jeg alle mine Forsætter. Det er min Skjæbne, og den bliver næppe anderledes, og jeg antager, at det vel omtrent gaar dig ligeledes. Der kan være liden Udsigt til Sejr baade for dig og mig, men vi faar trøste os med den Tanke, at vi dog kun har arbejdet for, hvad der efter vor Overbevisning var det rette og det gode. Mere kunne vi jo ikke gjøre.

\section{J. P. Junggreen til Gustav Johannsen.}

17. Nov. 1883. R. A.

Vi er ilde stedte med vor danske Skole efter Juhlers Død. ${ }^{1}$ ) Den bestaar vel endnu, men det er en offentlig Hemmelighed, som dog ikke maa omtales i Bladene, at det er Autoriteternes Hensigt at lukke den til Paaske.

Den betragtes som staaende i Rang med en saakaldt "Mellemskole«, og for at forestaa en saadan fordres der en saakaldt "Rectoratsexamen«. Denne har den unge Mand, der var Juhlers Medhjælper ikke og faar den naturligvis heller ikke, selv orn han, hvad jeg iøvrigt ikke ved, har de fornødne Kundskaber for at kunne tage den. Lige saa lidt er vi i Stand til at opdrive nogen anden Mand, der har den, og som kunde overtage Skolen. Yi har nu tænkt paa, om det ikke kunde lade sig gjøre at faa oprettet en ganske almindelig 2- eller 3-Klasses Borgerskole. Men baale Bekker og jeg har sogt $i$ alle de Love og administra-

1) J. C.. Juhler, der $1855-65$ havile været Lærer ved Aabenraa Borgrerskole, ledede fra 1866 til sin Død 1883 en privat Realskole i Byen. - Myndighederne nægtede Skolen Ret til at fortsærte. 
tive Bestemmelser ang. Skolevæsen, som han har, uden at være istand til at finde en positiv Udtalelse om, hvad der berettiger en Mand til at oprette og bestyre en saadan Skole.

Jeg har nu tænkt paa, om der ikke iblandt de Medlemmer af Rigsdagen, som du kender, skulde findes een eller anden, der vidste Beskjed om denne Sag og, hvis der existerer Lovbestemmelser derom, da kunde sige os, hvor de er at finde. Saavel Polakker som Katholikker leve jo dog i mange Henseenrler under lignende Forhold som vi. - $-\ldots$

\section{J. P. Junggreen til Villars Lunn.}

21. Marts 1884. Privateje.

- - Jeg seer jo, at Højre stadigt holder Møder hele 1.andet over; troer du at der er nogen Udsigt til at det vil frug. te, til at vort Land dog en Gang kan komme ud af den sorgelige og ydmygende Stilling, hvori det befinder sig. eller skal den nuværende Tilstand fortsattes, til Ordet Fædrelandskjærlighed kan slettes af den danske Ordbog, og til vort Folk forspilder Berettigelsen til at existere som selvstændigt. Gud hjælpe os, men undertiden synes jeg, at det fortjener intet bedre. Det er jo, som om hele den skandinaviske Race lidt efter lidt siger sig løs fra enhversomhelst ideel Opfattelse af Tilværelsen, som om Offerberedvilligheden, Viljen til at forsvare Fædrenes Land fuldstændig forsvinder, og som om det eneste, Bondestanden i de tre Lande bryder sig om, er at gjøre det mageligt for sig selv og saa surt som muligt for Regjeringen. Det forekommer mig undertiden, at vi, hvis Losen har været og er walt for Fædrelandet«, ere Epigoner, der i Virkeligheden tilhører en svunden Tidsalder, og at Bismarck faar Ret, naar han, som han har gjort det $\mathrm{i}$ disse Dage, siger, at Partikampene for Fremtiden kun ville dreje sig om økonomiske og materielle Spørgsmaal..- Dog nok herom! hvad end vor Skjæbne skal blive, saa kunne vi ikke "forandre Signaler«. Vi have hele vort Liv kjæmpet for Fædrelandets Ilee, og med den Fane ville vi gaa i Graven, men alılrig svigte den. 